UDC 378.011.3-051:51

DOI https://doi.org/10.31470/2415-3729-2020-12-229-247

\title{
Modeling of Continuous Professional Training of a Mathematics Teacher Using ICT
}

\section{Larysa Shevchuk}

Doctor of Philosophy in Pedagogy (Ph.D), Associate Professor Head of the Department of Mathematics, Computer Science, and Teaching Methods,

Pereiaslav-Khmelnytskyi Hryhorii Skovoroda State

Pedagogical University

$\bowtie$ 30, Sukhomlynskoho Str., Pereiaslav, Kyiv region, Ukraine, 08401

E-mail: held651@gmail.com

ORCID: http://orcid.org/0000-0002-8405-1168

Date of receipt of the article: September 28, 2020 Article accepted for publication: November 22, 2020

\section{Моделювання неперервної професійної підготовки вчителя математики до використання IKT}

\section{Лариса Дмитрівна Шевчук}

кандидат педагогічних наук, доцент, завідувач кафедри математики, інформатики та методики навчання, ДВНЗ «Переяслав-Хмельницький державний педагогічний університет імені Григорія Сковороди»,

$\triangle$ вул. Сухомлинського, 30, м. Переяслав, Київська обл., Україна, 08401

Дата надходження статті: 28 вересня 2020 p.

Стаття прийнята до друку: 22 листопада 2020 р. 


\section{Abstract}

Today, mathematical sciences play a special role in the life of society, because they serve the development of scientific, technological and technological progress, determine the prestige of the country on the world stage. In this context, it is important to continuously prepare future teachers of mathematics for further professional activities, which in accordance with the current needs of the individual, society, state, allows to create conditions for self-expression, self-realization and self-improvement.

The article is devoted to the issue of modeling the continuous professional training of mathematics teachers using ICT.

The research goal is to analyze modern models of future teacher training for the use of innovative tools and methods in their pedagogical activities, to present a structurally component model of continuous professional training of a future mathematics teacher using ICT. The following research methods were used: analysis of psychological and pedagogical literature on the research problem; synthesis and comparison; theoretical modeling.

The results. The main components of the structural model of continuous professional training of future mathematics teachers with the use of information and communication technologies are described. The main features of the new model of student training are identified: focusing on the need for lifelong learning; transformation of the bachelor's degree into the core of the educational system; providing students with a broad aspect of systematically updated master's programs, programs of professional and general cultural training and retraining; in the system of continuing education the key factor is the independent access of students to educational resources and innovative technologies of self-education; quality management of education based on a point-rating system to assess the level of students' mastery of academic disciplines. The directions of increase of efficiency of this process and ways of realization in practice of 
higher educational institutions of a pedagogical profile are allocated.

Conclusions. It is proved that the semantic component of modeling the continuous professional training of a future mathematics teacher with the use of ICT forms one of the main tasks of teaching mathematics - to establish a connection between a particular course and the relevant school subject. The integration of theoretical and practical training of future mathematics teachers in the system of continuing education contributes to the activation of students' cognitive activity, forming a holistic view of the future profession, creating optimal conditions for gaining solid knowledge and skills at work. The criterion-diagnostic component of the model provides for linear consistency between the monitoring of professional readiness, criteria and levels of its formation.

The model of forming the readiness of future mathematics teachers using ICT for professional activities in the system of continuous training helps to consider the structural elements and stages of preparation of future mathematics teachers for professional activities, the relationship between elements, design content, forms and methods of such training.

Key words: modeling of professional training, continuous professional training of a mathematics teacher, information and communication technologies, modeling method, readiness of a mathematics teacher for professional activity.

\section{References}

1. Kontseptsiia rozvytku profesiino-tekhnichnoi (profesiinoi) osvity v Ukraini. (2010). [The concept of development of vocational (professional) education in Ukraine] Profesiinotekhnichna osvita - Vocational and technical education, 3. 2-5 [in Ukrainian].

2. Modeliuvannia profesiinoi pidhotovky fakhivtsiv $\mathrm{v}$ umovakh yevrointehratsiinykh protsesiv (2019) [Modeling of professional training in the context of European integration processes. Monograph.]. In S.S. Vitvytskoi (Ed.). Zhytomyr: Vyd. O.O. Yevenok [in Ukrainian]. 
3. Pukhovska, L.P. (1997). Profesiina pidhotovka vchyteliv u Zakhidnii Yevropi: spilnist i rozbizhnosti [Teacher training in Western Europe: commonalities and differences]. Kyiv: Vyshcha shk [in Ukrainian].

4. Spirin, O.M., $\quad$ Yatsyshyn, A.V., $\quad$ Ivanova, S.M., Kilchenko, A.V. \& Luparenko, L.A. (2017). Model informatsiino-analitychnoi pidtrymky pedahohichnykh doslidzhen na osnovi elektronnykh system vidkrytoho dostup [Model of information-analytical support of pedagogical researches on the basis of electronic systems of open access]. Informatsiini tekhnolohii $i$ zasoby navchannia - Information technologies and teaching aids. Vol. 59, issue 3, 134-154 [in Ukrainian].

5. Fedotov, A.V. (1985). Modelirovanie v upravlenii vuzom [Modeling in university management]. Leningrad : Izd-vo Leningr. Un-ta [in Russian].

6. Shevchuk, L.D. (2019). Suchasnyi stan pidhotovky maibutnikh vchyteliv matematyky zasobamy IKT u systemi neperervnoi osvity. Innovatsiina pedahohika - Innovative pedagogy, 15(2), 166-170 [in Ukrainian].

7. Shtoff V.A. (1966). Modelirovanie i filosofija [Modeling and philosophy]. Moskva - Leningrad. Izd-vo Nauka [in Russian].

8. Iakubovski, M.A. (2004). Teoretyko-metodolohichni osnovy matematychnoho modeliuvannia profesiinoi diialnosti vchytelia [Theoretical and methodological bases of mathematical modeling of teachers professional activity]. Extended abstract of Doctors thesis. Kyiv: Institute of Pedagogy and Psychology of Vocational Education of the Academy of Pedagogical Sciences of Ukraine [in Ukrainian].

\section{Вступ}

Однією із принципово важливих і конструктивних ідей у стратегії підвищення інтелектуального потенціалу нації $є$ ідея випереджальної освіти, суть якої полягає в тому, щоб 
своєчасно підготувати людей до майбутнього ( Вітвицька, 2019). Сучасні зміни все більше перетворюють школу на систему відкриту для навколишнього світу. Життя у шкільному середовищі поступово стає моделлю поширеної молодіжної культури. У школі, класі здійснюється спільне життя, комунікація і самовираження молоді, які активно адаптуються до змін у суспільстві. Нові пріоритети, зокрема застосування можливостей цифрових технологій в навчальному процесі значно ускладнюють та урізноманітнюють роль і функції вчителя математики, який має реагувати на новий стан речей, бути готовим застосовувати інноваційні засоби та методи роботи (Пуховська, 1997 ). У зв’язку з цим виникає потреба у розробці моделі неперервної підготовки майбутнього викладача математики до використання цифрових технологій.

Особливістю моделювання педагогічної освіти є те, що модель майбутнього стану невизначена, багатогранна та змінюється на шляху досягнення мети (Якубовскі, 2004). Методологія моделювання зорієнтована на аналіз, визначення умов та шляхів розвитку педагогічної освіти i потребує формування багаторівневої системи моделей. Методологія аналізу розвитку педагогічної освіти має базуватися на пріоритеті свободи вибору педагогом та студентом засобів моделювання з урахуванням особистісних властивостей, відмінностей у наукових традиціях під час вибору як моделей, так і форм організації педагогічного процесу.

Метод моделювання $\epsilon$ предметом широкого використання в сучасних науково - педагогічних дослідженнях В. Гриньової, О. Дубасенюк, Н. Ничкало, С. Сисоєвої, В. Чайки, В. Чернілевського та ін., моделювання професіограми майбутнього вчителя розглядали В. Беспалько, Н. Кузьміна, А. Маркова, В. Сластьонін, підготовку майбутнього вчителя - О. Будник, Н. Глузман, 
О. Савченко, Л. Хомич та ін., моделюванню професійної діяльності присвятили свої дослідження С. Дружилов, О. Ігнатюк, О. Пономарьов, О. Романовський, В. Сергеєв та інші. Цікаві й плідні результати отримані завдяки моделюванню особистості фахівця, які виконували А. Ларіонова, А. Лурія, Г. Олпорт (G. Allport), О. Пономарьов, В. Рибалка та інші вчені.

Таким чином моделювання є невід'ємним аспектом у забезпеченні природної єдності навчання та наукових досліджень у педагогічному процесі. На думку В. Штоффа модель це така розумово реалізована система, яка, відображаючи та відтворюючи об'єкт дослідження, здатна замінити його так, щоб ії вивчення дало нам нову інформацію про цей об'єкт. Модель, як штучна система відображає 3 певною точністю основні властивості досліджуваного об'єкта оригіналу і може заміняти його у дослідженні, а також дозволяє отримати інформацію про цей об'єкт ( Штофф, 1966 ).

Метою статті є аналіз сучасних моделей підготовки майбутнього вчителя до використання інноваційних засобів та методів у своїй педагогічній діяльності, представлення структурно компонентної моделі неперервної підготовки майбутнього вчителя математики до використання IКТ.

\section{Матеріал і методи дослідження}

Розкриваючи суть методу моделювання, можна констатувати, що основою його є опосередковане оперування не безпосередньо об'єктом, а штучно створеною системою, яка знаходиться у тотожності необхідній до об'єкту пізнання (Федотов, 1985: 4). Тому головною проблемою методу моделювання, на думку більшості дослідників, є створення моделі, що в повній мірі відтворювала причинно-наслідкові зв'язки, що існують в реальному об'єкті (Федотов, 1985: 50).

Для досягнення поставлених цілей використовувались наступні методи дослідження: аналіз вітчизняної та зарубіжної психолого-педагогічної літератури з проблеми 
дослідження 3 метою визначення рівня розробленості досліджуваного питання; синтез і порівняння, що дало можливість визначити теоретико-методологічні засади, сутність і структуру досліджуваного феномену; теоретичне моделювання, яке дозволило розробити концептуальну модель неперервної професійної підготовки вчителів математики до використання IКТ в педагогічної діяльності.

\section{Результати та обговорення}

На стан професійної підготовки майбутніх вчителів впливає сукупність як внутрішніх факторів (освітні програми і стандарти, методична оснащеність, організація навчального процесу тощо) так i зовнішніх (державні стандарти, нормативно-правові документи, запити освітніх установ). У Концепції розвитку професійної освіти в Україні зазначається, що без якісної підготовки кваліфікованих спеціалістів, адаптованих до сучасних вимог технологічного розвитку галузей науки, що мають високий рівень теоретичної підготовки та професійної компетентності, володіють багатофункціональними практико орієнтованими вміннями, здатні до самоорганізації, самореалізації у професійній діяльності, готових до розв'язання виробничих завдань i соціально-економічних проблем, неможливо розвивати високотехнологічне суспільство. (Концепція розвитку професійно-технічної (професійної) освіти в Україні, 2010).

Тому розробка перспективних концептуальних моделей, технологій підготовки майбутніх вчителів математики має базуватися на всебічному та грунтовному аналізі сучасних тенденцій у міжнародному освітньому просторі, закономірностей розвитку суспільного життя, досягнень зарубіжної та вітчизняної філософської, психологопедагогічної науки і практики (Спірін, Яцишин, Іванова, Кільченко\&Лупаренко, 2017 ).

Аналізуючи сучасні моделі професійної підготовки вчителів математики та беручи до уваги процес оновлення 
вищої математичної освіти, зроблено висновок, що модель формування професійної готовності вчителів математики до використання IКТ в системі неперервної освіти повинна включати систему компонентів, які надають об'єктивну i достатньо повну інформацію про : мету, зміст, характер і результат їх педагогічної діяльності; складові процесу формування професійної компетентності вчителя математики в системі неперервної освіти; теоретико-методичне та інформаційне забезпечення неперервної професійної підготовки майбутніх фахівців та педагогічні умови іiі ефективності. При розробці моделі неперервної професійної підготовки вчителів математики засобами IКT використовувались загальновизнані у педагогічній науці методологічні орієнтири, зокрема: можливість створення ідеальної концептуальної моделі професійної компетентності фахівця; використання синергетичного підходу, оскільки він орієнтований на те, щоб виявити закономірності становлення і самоорганізації складних систем, що забезпечує вихід на індивідуальну траєкторію розвитку. У концептуальну модель включено п’ять блоків, які побудовані у спіральній та лінійній формах і дають уявлення про різні аспекти процесу формування професійної готовності вчителів математики засобами IКТ в системі неперервної освіти (рис.1). 


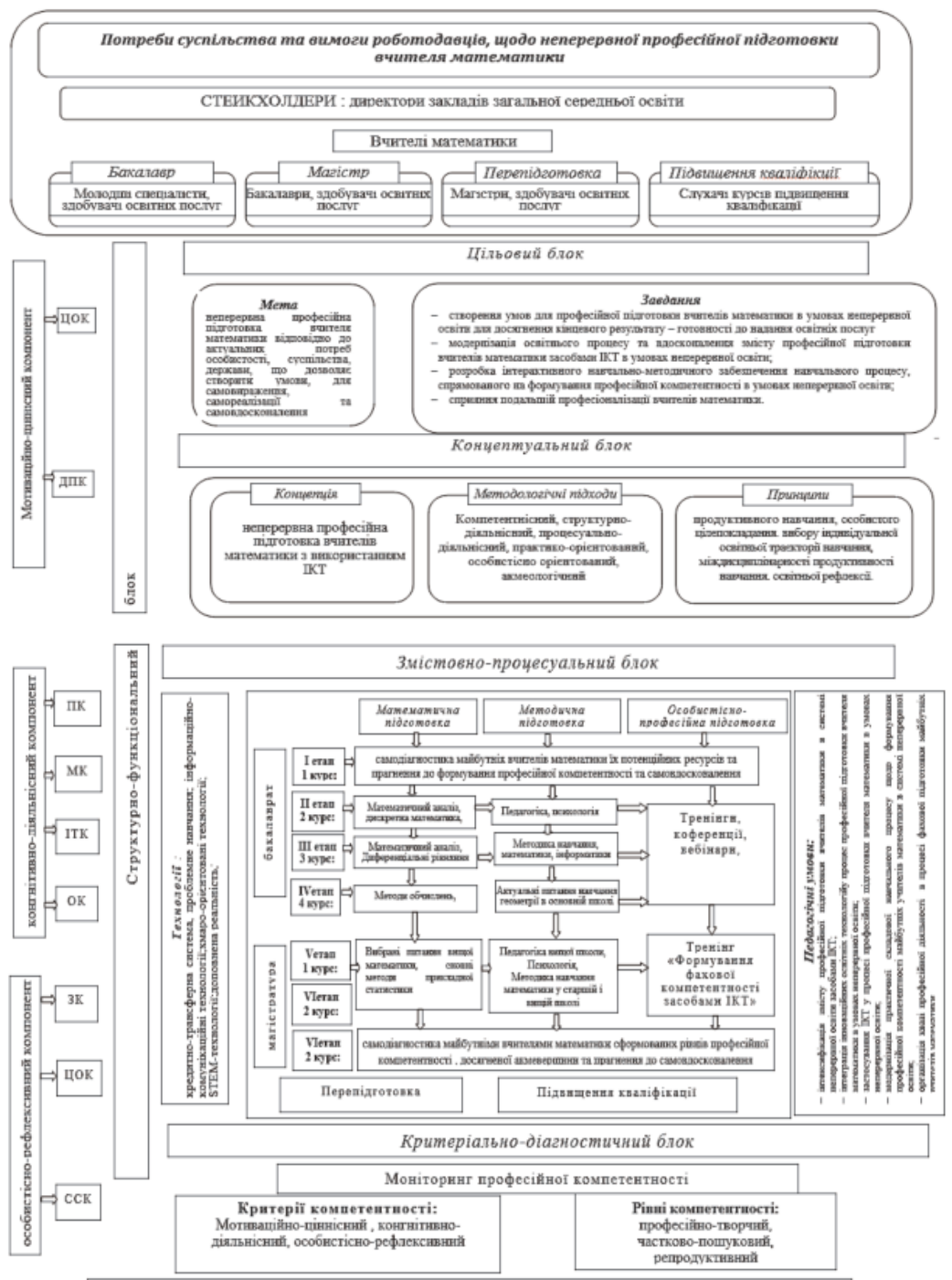

Результат: сформованість професійної компетентності вчителів математики засобами ІКТ в снстемі неперервної освіти

Рис. 1 Структурно-компонентна модель готовності вчителів математики до педагогічної діяльності з використанням IКТ в системі неперервної освіти 
У межах цільового блоку моделі визначено мету (неперервна професійна підготовка вчителя математики 3 використанням ІКТ відповідно до актуальних потреб особистості, суспільства, держави, що дозволяє створити умови, для самовираження, самореалізації та самовдосконалення ), завдання (створення умов для професійної підготовки вчителів математики в умовах неперервної освіти для досягнення кінцевого результату готовності до надання освітніх послуг в цифровому суспільстві; модернізація освітнього процесу та вдосконалення змісту неперервної професійної підготовки вчителів математики 3 використанням IKT в умовах неперервної освіти; розробка інтерактивного навчальнометодичного забезпечення навчального процесу, спрямованого на формування професійної готовності до використання IКТ в умовах неперервної освіти; сприяння подальшій професіоналізації вчителів математики).

У межах концептуального блоку визначена концепція неперервної професійної підготовки вчителів математики 3 використанням IKT та методологічні підходи (компетентнісний, структурно-діяльнісний, процесуальнодіяльнісний, практико-орієнтований, особистісно оріентований, акмеологічний), виокремлено педагогічні принципи (принципи продуктивного навчання, особистого ціле покладання, вибору індивідуальної освітньої траєкторії навчання, міждисциплінарності продуктивності навчання, освітньої рефлексії)

Третю площину - структурно-функціональну, наведено у спіральній формі, що віддзеркалює взаємозв'язок компонентів та складових професійної компетентності, що є невід'ємною частиною професійної готовності: ціннісноорієнтаційної (ЦОК), диференційовано-психологічної (ДПК), предметної (ПК), методичної (МК), інформаційнотехнологічної (ІTK), організаційної (ОК), соціально-комунікативної (СКК), творчо-інноваційної (ТІК), здоров’ язберігаючої (ЗК). 
Змістовно-процесуальний блок моделі формування професійної компетентності вчителя математики засобами IКТ в системі неперервної освіти дає уяву про математичну, методичну та особистісно-професійну підготовку студентів на бакалавраті, магістратурі та перепідготовці чи підвищення кваліфікації, технології та педагогічні умови ефективного засвоєння знань, умінь та навичок і формування досвіду майбутньої професійної діяльності, що впливає на розвиток професійних якостей майбутнього вчителя математики.

Практика доводить, що пошук умов, що покращують процес засвоєння знань та забезпечують отримання професійного досвіду студентами, залежить від уміння викладачів використовувати різні інформаційнокомунікаційні технології для розв'язування задач, які максимально наближені за своїм змістом до майбутньої професійної діяльності; інтеграції інноваційних освітніх технологій у процес професійної підготовки вчителя математики в умовах неперервної освіти та модернізації практичної складової навчального процесу щодо формування професійної компетентності майбутніх учителів математики в системі неперервної освіти.

Під компетентнісним досвідом розуміємо цілеспрямований процес щодо виконання певних видів діяльності у процесі розв'язання прикладних, професійних задач. Основою цього блоку моделі є педагогічні умови, технології та комплексна програма їх реалізації. У процесі виділення педагогічних умов забезпечення ефективності формування у майбутніх вчителів математики професійної компетентності та готовності до використання IКТ в умовах неперервної підготовки враховано вплив різних аспектів інноваційного освітнього середовища, а саме:

- інтенсифікація змісту професійної підготовки вчителів математики в системі неперервної освіти засобами IКТ (аспект впливу навчального і виховного середовища); 
- інтеграція інноваційних освітніх технологій у процес професійної підготовки вчителя математики в умовах неперервної освіти(аспект впливу розвивального середовища).

- застосування IКТ у процесі професійної підготовки вчителя математики в умовах неперервної освіти (аспект впливу інформаційно-освітнього середовища);

- модернізація практичної складової навчального процесу щодо формування професійної компетентності та готовності до професійної діяльності майбутніх учителів математики в системі неперервної освіти(аспект впливу творчого діяльнісного середовища);

- організація квазі професійної діяльності в процесі фахової підготовки майбутніх вчителів математики (аспект впливу соціального і професійного середовища)

Наступним блоком моделі - критеріальнодіагностичним передбачено лінійну узгодженість між моніторингом професійної компетентності, критеріями та рівнями їі сформованості. У дослідженні виділено наступні критерії професійної компетентності вчителя математики до застосування інноваційної діяльності: мотиваційноціннісний (ціннісне ставлення до життєдіяльності; спрямованість на використання сучасних інформаційнокомунікаційних технологій у професійній діяльності), інформаційно-когнітивний (розуміння сутності та особливостей використання сучасних інформаційнокомунікаційних технологій професійної діяльності; активність та здатність до пошуку інновацій та їх реалізації), операційно-креативний (здібності до використання сучасних інформаційно-комунікаційних технологій в професійній діяльності; готовність до практичної реалізації інновацій в освіті); особистісно-рефлексивний (орієнтація на професійне самовдосконалення і саморозвиток ). Цими критеріями передбачено прояв таких показників професійної готовності майбутніх учителів математики до використання сучасних 
інформаційно-комунікаційних технологій в системі неперервної освіти:

- розуміння студентами необхідності вивчення дисципліни «математика», ㄲi значення в подальшій навчальній та у майбутній професійній діяльності, професійна спрямованість особистості, ставлення до педагогічної діяльності, стимулювання позитивної мотивації учнів до навчання;

- системність професійних знань, фундаментальні теоретичні математичні знання, знання алгоритмів і методів розв'язання математичних задач, як традиційними так i інноваційними засобами для вирішення завдань майбутньої професійної діяльності, а також для продовження освіти;

- вміння визначати стратегію майбутньої педагогічної діяльності, володіння різними методами, прийомами, методиками у процесі професійної діяльності, неодноразово реалізовані здібності до застосування не тільки вже відомих умінь, навичок і відповідних знань (в репродуктивній діяльності), а й освоєння нового їх набору (у творчій діяльності) при вирішенні математичних і прикладних задач 3 використанням сучасних інформаційно-комунікаційних технологій;

- використання сучасних педагогічних та інформаційнокомунікаційних технологій технологій у практичній діяльності, вміння раціоналізувати свою діяльність і діяльність учнів як у виборі способів при вирішенні завдань, так і у виборі засобів навчання, зокрема IКT;

- вміння аналізувати, осмислювати, усвідомлювати процеси і результати власної та колективної діяльності при вирішенні прикладних математичних задач, вміння критично оцінювати і коригувати діяльність при необхідності.

- уміння ініціювати дослідницькоінноваційні проекти, генерувати творчі ідеї, здатність до саморозвитку i самовдосконалення впродовж життя. 
Предметом моніторингу є відносини між результатами діагностики станів окремих компонентів професійної компетентності майбутніх учителів математики, що дають уявлення про рівні професійної компетентності.

Високий (професійно-творчий) рівень професійної готовності майбутніх учителів математики в умовах неперервної підготовки характеризується спрямованістю на справу, позитивним ставленням до педагогічної діяльності та здатністю iii прогнозувати i планувати; постійним стимулюванням мотивації учнів до навчання математики; високим рівнем знань та фахових умінь; досконалим володінням різними методами, прийомами, новітніми технологіями у викладанні математики та здатністю їх використовувати на практиці; наявністю навичок ефективного оперування інформацією; вмінням ефективно організувати діяльність учнів у навчально-виховному процесі; здатністю до саморозвитку і самовдосконалення впродовж життя.

Середній (частково-пошуковий) рівень професійної компетентності майбутніх учителів математики характеризується наявністю спрямованості на спілкування, епізодичним стимулюванням позитивної мотивації учнів до навчання математики; середнім рівнем знань та частковою сформованістю фахових умінь, що дають змогу здебільшого успішно розв'язувати професійні задачі 3 переважним орієнтуванням на зразок; недостатньо сформованими вміннями визначати стратегію майбутньої педагогічної діяльності; переважанням у практиці роботи традиційних методів, прийомів і технологій, випадкової потреби у використання сучасних інформаційно-комунікаційних технологій; наявністю спроб організувати свою діяльність і діяльність учнів у навчально-виховному процесі; частковим оволодінням прийомами міжособистісного спілкування та сформованістю особистісних якостей; невисокою творчою 
активністю та переважанням відсутності бажання пошуку нових способів дій у нестандартних ситуаціях; частково сформованою здатністю до саморозвитку i самовдосконалення впродовж життя.

Низький (репродуктивний) рівень професійної компетентності майбутніх учителів математики в умовах неперервної підготовки характеризується наявністю спрямованості на себе, індиферентним ставленням до педагогічної діяльності; недосконалим стимулюванням позитивної мотивації учнів до навчання математики; недостатнім рівнем базових знань та фахових умінь для успішного здійснення професійної діяльності; неспроможністю визначати стратегію майбутньої педагогічної діяльності; використанням у практиці роботи лише традиційних методів, прийомів, технологій та відсутністю бажання в придбанні і використанні нової інформації; труднощами в організації власної й учнівської діяльності; наявністю конфліктів у взаєминах з оточуючими, сформованістю лише деяких особистісних якостей; наданням переваги інтуїції при розв'язуванні творчих завдань, небажанням генерувати творчі ідеї; несформованою здатністю до саморозвитку і самовдосконалення впродовж життя.

\section{Висновки}

Узагальнюючи вище викладене, можна стверджувати, що професійне становлення майбутніх учителів математики у системі вищої освіти здійснюється як під час теоретичної та практичної підготовки у закладах вищої освіти при здобутті рінів бакалавра та магістра так і при перепідготовці та підвищенні кваліфікації, тому створена створена концептуальна модель готовності вчителів математики до педагогічної діяльності з використанням IКT в системі неперервної освіти дозволить сформувати у студентів високий рівень теоретичної підготовки та професійної 
компетентності, здатність до самоорганізації, самореалізації у професійній діяльності. Ці узагальнення дають підстави для перевірки оптимальних умов застосування інформаційно-комунікаційних технологій у неперервній підготовці майбутніх вчителів математики.

\section{Література}

1. Концепція розвитку професійно-технічної (професійної) освіти в Україні. Професійно-технічна освіта : науково-методичний журнал. 2010. №3. С. 2-5.

2. Моделювання професійної підготовки фахівців в умовах євроінтеграційних процесів: монографія / за ред. С.С. Вітвицької, доктора педагогічних наук, професора. Житомир: Вид. О.О. Свенок, 2019. 304 с.

3. Пуховська Л.П. Професійна підготовка вчителів у Західній Європі: спільність і розбіжності: монографія. Київ: Вища шк., 1997. 179 с.

4. Спірін О.М., Яцишин А.В., ванова С.M., Кільченко А.В., Лупаренко Л.А. Модель інформаційноаналітичної підтримки педагогічних досліджень на основі електронних систем відкритого доступу. Інформаційні технології і засоби навчання. 2017. Т. 59, вип. 3. С. 134-154.

5. Федотов А.В. Моделирование в управлении вузом. Ленинград : Изд-во Ленингр. Ун-та, 1985. 120 с.

6. Шевчук Л.Д. Сучасний стан підготовки майбутніх вчителів математики засобами IКТ у системі неперервної освіти. Інноваційна педагогіка. 2019. Випуск 15. Т. 2. C.166-170.

7. Штофф В.А. Моделирование и философия. Москва Ленинград. Изд-во Наука, 1966. 304с.

8. Якубовскі М.А. Теоретико-методологічні основи математичного моделювання професійної діяльності вчителя : автореф. дис. ...д-ра пед.наук : спец. 13.00.04 / Ін-т педагогіки і психології професійної освіти АПН України. Київ, 2004. 40 с. 
Шевчук Л.Д.

\section{Моделювання неперервної професійної підготовки вчителя математики з використанням IKT}

\section{Анотація}

Стаття призначена питанню моделювання неперервної професійної підготовки вчителя математики з використанням IKT. Описані основні компоненти структурної моделі неперервної професійної підготовки майбутніх вчителів математики з використанням інформаційно-комунікативних технологій. Визначено головні ознаки нової моделі підготовки студентів: фокусування уваги на необхідності отримання освіти протягом усього життя; перетворення бакалаврату в ядро освітньої системи; надання студентам широкого аспекту систематично оновлюваних магістерських програм, програм професійної та загальнокультурної підготовки та перепідготовки; в системі неперервної освіти ключовим фактором стає самостійний доступ студентів до навчальних ресурсів та інноваційних технологій самоосвіти; менеджмент якості освіти на основі бально-рейтингової системи для оцінки рівня оволодіння студентами навчальними дисциплінами. Виокремлено напрями підвищення ефективності цього процесу та шляхи реалізації в практиці вищих навчальних закладів педагогічного профілю. Доведено, що змістова складова моделювання неперервної професійної підготовки майбутнього вчителя математики з використанням IКТ формує одне з головних завдань навчання математичним дисциплінам - установлення зв'язку між конкретним курсом і відповідним шкільним предметом.

Ключові слова: моделювання професійної підготовки, неперервна професійна підготовка вчителя математики, інформаційно-комунікаційні технології, метод моделювання, готовність вчителя математики до професійної діяльності. 
Шевчук Л.Д.

\section{Моделирование непрерывной профессиональной подготовки учителя математики с использованием ИКТ}

\section{Аннотация}

Статья предназначена вопросу моделирования непрерывной профессиональной подготовки учителя математики с использованием ИКТ. Описаны основные компоненты структурной модели непрерывной профессиональной подготовки будущих учителей математики с использованием информационнокоммуникационных технологий. Определены главные признаки новой модели подготовки студентов: фокусирование внимания на необходимости получения образования в течение всей жизни; преобразования бакалавриата в ядро образовательной системы; предоставление студентам широкого аспекта систематически обновляемых магистерских программ, программ профессиональной и общекультурной подготовки и переподготовки; в системе непрерывного образования ключевым фактором становится самостоятельный доступ студентов к учебным ресурсам и инновационным технологиям самообразования; менеджмент качества образования на основе бально-рейтинговой системы для оценки уровня овладения студентами матеріалами учебных дисциплин. Выделены направления повышения эффективности этого процесса и пути реализации в практике высших учебных заведений педагогического профиля. Доказано, что содержательная составляющая моделирования непрерывной профессиональной подготовки будущего учителя математики с использованием ИКТ формирует одну из главных задач обучения математическим дисциплинам установление связи между конкретным курсом и соответствующим школьным предметом. 
Ключевые слова: моделирование профессиональной подготовки, непрерывная профессиональная подготовка учителя математики, информационно-коммуникационные технологии, метод моделирования, готовность учителя математики к профессиональной деятельности. 